\title{
Dampak Fenomena Wisata Kuliner Terhadap Kunjungan Wisatawan di Kota Malang, Jawa Timur
}

Dimas Prayogo a, 1, Ida Bagus Suryawan a, 2

1kenapadimas27@gmail.com,2idabagussuryawan@unud.ac.id

a Program Studi S1 Destinasi Pariwisata, Fakultas Pariwisata,Universitas Udayana, Jl. Dr. R. Goris, Denpasar, Bali 80232 Indonesia

\section{Abstract}

This research discusses about the phenomenon impact of culinary tourism in Malang City, East Java. Which is analyze the characteristic of the tourist such as age, job, and where they from. The impact of culinary tourism phenomenon analyze with the aspect of positive and the negative. The point of view for the impact is in 3 (three) point such as economy, social culture, and the environment.

The result of this study is the numbers of tourist departure always raising which is the point of view is still positive. The age of the tourists dominated in $21-30$ years old. Tourist typology that come to Malang City is incipient mass, the tourist is very considerable about standard of the culinary but they still want the authentic of culinary itself.

The impact of culinary tourism is showing the positive result, the tourist and local people feels that culinary tourism make he economy in Malang city being increased and also tourist can learn about the culture.

\section{Keywords : Phenomenon, Impact, Culinary Tourism, Malang City}

\section{PENDAHULUAN}

Wisata kuliner adalah salah satu jenis wisata yang menjadi sebuah fenomena baru dalam pariwisata menjadikan sebuah semarak dalam hal yang dapat di kembangkan. Pilihanpilihan usaha kuliner yang merupakan salah satu dari bidang pariwisata yang sangat diminati oleh masyarakat maupun pengusaha swasta. Para stakeholder dalam bidang wisata kuliner terus bersinergi dalam menyajikan produk pariwisata yang dimiliki yakni hotel, penginapan, cafe, restoran, bahkan rumah makan yang juga menjadi pilihan usaha untuk dijalankan.

Kunjungan wisatawan di Kota Malang pada tahun 2010 sebanyak 169.645 orang, tahun 2011 sebanyak 190.028 orang, tahun 2012 sebanyak 224.660 orang, tahun 2013 sebanyak 283.148 orang, tahun 2014 kedatangan wisatawan sebanyak 298.075 orang, serta pada tahun 2015 kedatangan wisatawan ke Kota Malang sebanyak 304.479 orang (Malang dalam angka, 2015).

Seiring maraknya fenomena wisata kuliner di Kota Malang inilah yang membuat Kota Malang terus optimis untuk menjadi salah satu Kota yang menjadikan wisata kuliner sebagai salah satu trade mark yang diandalkan. Bakso Bakar Pak Man, Bakso President, Toko Oen, Depot Hoklay dan Warung Ronde Titoni adalah contoh-contoh kuliner yang menjadi tujuan para wisatawan kuliner di Kota Malang.

Penelitian ini bertujuan untuk mengidentifikasi berbagai dampak dari kunjungan wisatawan di Kota Malang Jawa Timur. Jumlah kunjungan wisatawan Kota Malang tiap tahun mengalami kenaikan kunjungan wisatawan, juga bersamaan seiring berkembangnya fenomena wisata dengan tinjauan teori dampak pariwisata yang menyatakan dampak positif serta dampak negatif kegiatan pariwisata diwakilkan oleh sebuah penilaian atau value judgment untuk meninjau adanya fenomena wisata kuliner (Mill, 2000). Penelitian mengenai wisata kuliner ini diharapkan dapat lebih ditindak lanjuti oleh para peneliti lain. Sasaran dalam penelitian ini yakni mengetahui bagaimana karakteristik wisatawan kuliner yang melakukan perjalanan nya di Kota Malang Jawa Timur serta meninjau bagaimana dampak dari adannya fenomena wisata kuliner di Kota Malang Jawa Timur

Dampak yang dapat ditimbulkan dari kegiatan wisata kuliner dalam hal-hal yang dapat dikaji. Wisata kuliner merupakan salah satu daya tarik bagi wisatawan yang mengadakan suatu perjalanan wisata dengan tujuan untuk menikmati berbagai jenis makanan yang memiliki cita rasa unik yang diinginkan oleh para wisatawan kuliner di Kota Malang Jawa Timur. 


\section{Tinjauan Pustaka}

Konsep yang digunakan dalam penelitian ini yaitu konsep-konsep mengenai karakteristik tipologi wisatawan yang dibagi dalam berbagai klasifikasi yaitu offbeat, unusual, incipient mass dan mass, charter dan elite (Pitana 2005). Karakteristik wisatawan yang dibagi dalam 5 klasifikasi organized mass touris, individual mass tourist, exporer dan drifter (Pitana 2005) dan juga konsep wisata kuliner yang menyatakan bahwa wisata kuliner adalah rangkaian kegiatan untuk mengunjungi tempattempat kuliner yang antara lain restaurant, kafe, festival makanan serta produsenprodusen makanan di suatu daerah yang ingin dikunjungi (Hall dan Mitchel 2011). Untuk menunjang korelasi antara hasil temuantemuan peneliti selama di lapangan dan hasil pembahasan serta simpulan terkait penelitian mengenai wisata kuliner ini. Wisata kuliner perlu dilakukan pembedaan antara wisatawan yang mengkonsumsi suatu makanan sebagai bagian dari pengalaman berwisata dengan wisatawan yang hanya beraktivitas, bertingkah laku, atau memilih destinasi yang berbau kuliner tanpa mempertimbangkan faktor pengalaman dalam berwisata (Hall dan Mitchel 2011).

\section{METODE}

Penelitian ini diambil di lokasi Kota Malang, Jawa Timur. Dimana letak persis yang dituju adalah di kawasan Kelurahan Ketawanggede Kecamatan Lowokwaru. Kawasan ini dijadikan lokasi penelitian dikarenakan banyaknya sajian kuliner yang sangat diminati serta sangat dinikmati oleh para wisatawan. Tidak hanya sajian lezat yang ditawarkan, namun ada sisi lain yang juga ingin diketahui oleh para wisatawan, yaitu bagaimana sejarah sebuah kuliner dapat dikenal dan bertahan hingga zaman modern seperti ini. Contoh-contoh kuliner yang bersejarah namun masih menjaga kualitas nya sampai saat ini yaitu Toko Oen, Bakso Pak Man, Warung Ronde Titoni, serta Depot Gang Djangkrik.

Pengumpulan data menggunakan observasi, kuesioner, wawancara, studi kepustakaan, dan dokumentasi. Teknik penentuan sampel yang digunakan dalam penelitian ini yaitu dengan cara emergent sampling design (Sugiyono 2012). Teknik analisis data yang digunakan melalui Pengumpulan Data, Reduksi Data, Penyajian Data (Bungin 2003). Langkah terakhir untuk penelitian yaitu melalui langkah verifikasi data serta penarikan dan penegasan kesimpulan dengan didukung pola penghitungan metode skala likert (Arikunto 2002).

\section{HASIL DAN PEMBAHASAN}

Kota di Jawa Timur kedua yakni Kota Malang memiliki total luas sebesar 110,06 km2, yang terdiri dari 5 Kecamatan (Malang dalam angka, 2015). Kuliner khas Kota Malang yang sangat diminati oleh wisatawan dibagi menjadi 5 tempat yang di favoritkan dijadikan lokasilokasi yang diteliti dalam penelitian ini.

Wisata kuliner di Kota Malang yang sangat beragam dalam segi pilihan, rasa serta kualitas lah yang menjadikan para wisatawan kuliner semakin tertarik dalam melakukan perjalanan wisata kuliner nya. Selain mdari pada itu beberapa tempat kuliner khas kota Malang memang menyajikan kuliner khas nya dengan sangat menarik dalam segi unsur klasik yang memang masih dijaga sampai saat ini. Festivalfestival makanan juga adalah salah satu kegiatan yang ditunggu-tunggu bagi masyarakat Kota Malang dan juga para wisatawan kuliner yang berkunjung ke Kota Malang.

Berdasarkan hasil data dilapangan yang ditemukanoleh peneliti bahwa besaran jumlah wisatawan yang berkunjung ke Kota Malang berjumlah $72 \%$ yang masuk dalam kategori wisatawan incipient mass sedangkan jumlah besaran wisatawan dalam kategori mass berjumlah 28\% dengan selisih yang cukup jauh dari kategori sebelumnya. Pemilihan tempattempat kuliner yang ingin dikunjungi pun sangat berpengaruh dari tipologi wisatawan kuliner. Wisatawan yang termasuk dalam kategori incipient mass cenderung masih memilih dengan cukup selektif tempat-tempat wisata kuliner Kota Malang yang mana saja sekira nya ingin mereka kunjungi, karena batasan-batasan yang sudah ditentukan sebelum sampai di Kota Malang. Sedangkan wisatawan dengan jenis tipologi mass cenderung mengunjungi tempat-tempat wisata kuliner yang sudah dikenal atau dalam istilah lain yaitu mainstream.

Pemilihan serta penggunaan tipe hotel yang dipilih secara langsung oleh wisatawan dalam kategori incipient mass dan kategori mass yaitu tipe-tipe hotel yang ada di suatu daerah yang biasa nya sudah memiliki berbagai fasilitas 
sesuai standar dengan harapan wisatawan kuliner dapat dimanjakan dengan kenyamanan yang telah disediakan oleh hotel tersebut. Akomodasi lainnya yang tidak sesusai dengan standar atau cenderung berbeda dari daerah asal wisatawan tersebut pada umumnya tidak menjadi pilihan oleh para wisatawan kuliner. Hal ini juga berdampak pada stakeholder dalam bidang bisnis akomodasi yaitu hotel dan restoran terus memperbaiki fasilitas yang disediakan dan terus disesuaikan dengan standar yang diinginkan oleh para wisatawan terutama wisatawan kuliner yang berkunjung ke Kota Malang, Jawa Timur.

Hal yang dirasa perlu untuk terus mempertahankan segmen pasar wisatawan mass dan tipe wisatawan incipient mass perlu untuk ditindak lanjuti perluasan serta penyebaran nya karena dari hasil yang ditunjukan dalam angka bahwa angka tingkat kunjungan dalam 2 kategori wisatawan tersebut cukup signifikan.

Responden atau wisatawan kuliner dengan jumlah terbesar berasal dari Kota Mojokerto serta jumlah terkecil dari kota Klaten yang masing-masing berjumlah $23 \%$ dari Kota Mojokerto serta Kota Klaten berjumlah 1\% menunjukkan bahwa hasil dari penyelenggaraan fenomena wisata kuliner masih terus berkembang dalam segmen pasar wisatawan domestic atau yang berasal dari Indonesia. Cakupan wilayah wisatawan yang datang ke Kota Malang juga masih didominasi dari kota-kota di Jawa Timur. Dengan kata lain wisatawan yang berasal dari Indonesia dengan jumlah 95\% dari total 100 responden dan wisatawan mancanegara dengan jumlah 5\% yang berasal dari Belanda dan Jerman, angka wisatawan mancanegara masih sangat kurang penyerapan nya untuk wisatawan kuliner yang berkunjung ke Kota Malang.

Hal tersebut masih dibutuhkan perhatian oleh para stakeholder terkait pariwisata dan wisata kuliner untuk terus membuat penyelenggaraan wisata kuliner diKota Malang menjadi value image yang berkelanjutan. Wisatawan kuliner yang berkunjung ke Kota Malang juga masih di dominasi oleh wisatawan yang masuk dalam kategori umur 21-30 tahun dimana usia tersebut adalah usia produktif yang masih menginginkan wisata dengan pengalaman baru yang bisa didapatkan di Kota Malang dengan melakukan kunjungan- kunjungan ke tempat-tempat kuliner yang sudah cukup dikenal oleh wisatawan lainnya. Sedangkan serapan wisatwan yang dapat dikategorikan dari segi umur 40 tahun keatas masih sangat minim dengan total serapan sebanyak 5\% dari 100 responden yang didapatkan oleh peneliti.

Wisatawan yang berumur 40 tahun keatas melakukan perjalanan biasa nya dengan keluarga atau jumlahnya kelompok karena kesulitan dalam mengatur itinerary secara independen atau dengan kata lain tanpa menggunakan jasa travel agent.

Kunjungan Wisatawan di Kota Malang selalu mengalami peningkatan dari tahun ke tahun. Pada Tahun 2011 Kota Malang mengalami kenaikan kunjungan wisatawan yang cukup banyak yaitu dari 169.645 orang menjadi 190.028 orang. Pada tahun 2015 adannya lonjakan kedatangan wisatawan yang paling banyak yaitu berjumlah 304.479 orang. Daya penarik Kota Malang yang menjadikan wisata Wisata kuliner sebagai acuan utama untuk penyerapan wisatawan dianggap masih perlu untuk dipertahankan karena dampak dari penyelenggaraan wisata kuliner ini masih sangat minim terkait dampak negatif yang ditimbulkan. Karakteristik wisatawan yang mass terbagi atas 2 klasifikasi yakni wisatawan tipe individual mass tourist serta organized mass tourist dimana wisatawan yang berkunjung ke Kota Malang kebanyakan masuk dalam kategori individual mass tourist yang membuat itinerary untuk mengunjungi destinasi wisata, pembelian tiket serta pola mobilitas wisata kuliner dengan cara individu atau dengan kata lain tidak menggunakan jasa agen travel, namun masih ada pula wisatawan yang menggunakan jasa agen travel untuk mengurus segala keperluan yang dibutuhkan oleh wisatawan kuliner yang mengunjungi Kota Malang dengan alasan ekspektasi yang tinggi terhadap pelayanan serta pertimbangan efisiensi dalam segi waktu yang dihabiskan selama masa liburan di Kota malang.

Fenomena baru semacam ini yang langsung mendapat perhatian oleh wisatawan harus diiringi dengan niat dan kiat-kiat untuk terus dikembangkan dengan hal-hal yang disesuaikan dari adannya permintaan (demand) dari para wisatawan kuliner. Nilai Plus tersebut ditunjang dengan semaraknya para masyarakat lokal dalam membuka lapangan kerja sebagai 
pegiat kuliner untuk bersaing mendapatkan wisatawan kuliner yang berkunjung ke Kota Malang dan bantuan-bantuan dari pemerintah dalam penyelenggaraan berbagai festival yang rutin dilakukan setiap tahunnya di Balai Kota.

Dampak yang ditimbulkan dari adannya fenomena wisata kuliner serta penyelenggaraannya dalam segi ekonomi, lingkungan serta sosial budaya masih terbilang minim dari segi negative impact. Hal ini didapatkan dari keadaan di Kota Malang yang masih terbilang minim polusi udara serta kemacetan yang tidak terlalu mengganggu penyelenggaran kegiatan lain di Kota tersebut.

Terbuka lebar nya lapangan pekerjaan baru untuk para masyarakat lokal juga menunjukan hasil yang positif dalam aspek sosial budaya, ditambah lagi dengan adannya dukungan dari pemerintah dalam hal pengadaan festivalfestival makanan yang membuat semangat para pegiat kuliner di Kota Malang menjadi meningkat dalam hal produktifitas kuliner yang dihasilkan. Pendapatan para pegiat kuliner pun dari tahun ke tahun semakin meningkat dari adannya semarak fenomena wisata kuliner yang terus berkembang ini. Tidak hanya itu, pemerintah dalam hal pendapatan daerah juga semakin meningkat dari daya serapan yang dihasilkan oleh tingkat kunjungan wisatawan yang berkunjung ke Kota Malang, Jawa Timur.

Dari dampak negatif yang ditimbulkan dengan sangat minim maka dapat diperkirakan untuk fenomena wisata kuliner iniakan terus berlanjut kedepannya dengan berbagai inovasiinovasi kuliner yang terus berkembang, dengan diiringi terjaga nya antusiasme masyarakat dalam mengedepankan wisata kuliner sebagai mata lahan bisnis yang dapat menghasilkan keuntungan yang besar. Selain itu, wisatawan yang berkunjung ke Kota Malang setidaknya menghabiskan masa liburan mereka selama di Kota Malang juga untuk mencicipi berbagai kuliner yang memiliki cita rasa khas authentic yang diinginkan.

Berdasarkan 2 tipe wisatawan yang berkunjung ke Kota Malang yakni mass dan incipient mass cenderung melakukan pembelanjaan yang tinggi dalam melakukan perjalanan nya di Kota Malang, hal ini justru menguntungkan pusat oleh-oleh yang ada di Kota Malang serta para pegiat kuliner lainnya. Kota Malang yang identik dengan apel juga mengolah buah tersebut untuk dijadikan kudapan berupa keripik dimana keripik apel tersebut hanya bisa di temukan di Kota Malang. Jika pusat oleh-oleh sebagai bagian dari wisata kuliner semakin diramaikan oleh para wisatawan kuliner maka tidak hanya pegiat kuliner serta produsen makanan saja yang diuntungkan, melainkan para petani sebagai penyuplai bahan mentah pun merasakan keuntungan lebih dari kegiatan wisata kuliner.

Wisata kuliner yang berada di jantung Kota Malang yang antara lain Bakso Bakar Cak Man, Bakso president dan ketiga tempat lainnya dalam fokus penelitian ini menjadikan tempattempat tersebut mudah di akses oleh wisatawan dari stasiun serta Bandar udara di Kota Malang. Kelima tempat tersebut juga berdekatan dengan destinasi-destinasi pariwisata yang sudah sangat terkenal yakni sawojajar, lawang, serta kampung warna-warni jodipan. Maka daya jual dari wisata kuliner terbukti bersinergi dalam penyelenggaraan pariwisata di sektor lain.

Pengembangan wisata kuliner yang terus maju dalam kreatifitas serta produktifitas para pegiat kuliner sangat dibutuhkan untuk terus menjadi daya serapan wisatawan kuliner ke Kota Malang.

Perkembangan yang cukup pesat dalam bidang wisata kuliner di Kota Malang menjadikan masyarakat dari kota-kota lain di Jawa Timur lainnya berhijrah ke Kota Malang untuk membuka usaha dalam bidang wisata kuliner. Pendapatan per hari hingga per bulan yang cukup menjanjikan membuat masyarakat dari kota lain tergiur untuk berpartisipasi dalam bidang wisata kuliner ini. Serapan penduduk serta pendapatan daerah pun menjadi meningkat di Kota Malang dengan di dukung perputaran uang yang cukup sibuk di daerah-daerah yang ramai seperti daerah kecamatan Lowokwaru yang notabene banyak menampung tempat-tempat wisata kuliner yang ramai dikunjungi oleh wisatawan kuliner.

Rata-rata para pegiat kuliner yang datang ke Kota Malang berasal dari kota Lamongan, Surabaya, Kediri, serta Pasuruan. Mereka mencoba peruntungan nya dalam berusaha di kuliner yang dianggap sangat-sangat menjanjikan. Tidak hanya membuka usaha dan memposisikan diri sebagai pengusaha di bidang kuliner, masyarakat dengan keterbatasan ilmu dan fisik pun datang ke Kota Malang untuk mencari pekerjaan di tempat-tempat usaha 
kuliner yang sudah ramai dikunjungi oleh wisatawan dengan harapan gaji tinggi dikarenakan tempat kuliner tersebut sudah berhasil.

\section{SIMPULAN DAN SARAN}

Kesimpulan dalam penelitian ini yaitu karakteristik wisatawan dalam tipe incipient mass dan juga wisatawan dalam tipe mass masih sangat mendominasi kunjungan ke Kota Malang yang dikarenakan pemilihan tempattempat DTW atau wisata kuliner yang dipertimbangkan dengan berbagai aspek yang sesuai standar. Wisatawan kuliner yang mengunjungi tempat-tempat kuliner di Kota Malang termasuk dalam kategori Individual Mass Tourist dimana pengaturan itinerary yang dikunjungi di Kota Malang terutama wisata kuliner diatur sendiri oleh wisatawan tersebut, sedangkan jumlah yang sangat sedikit dari kategori Organized Mass Tourist yang notabene mengatur segala sesuatu yang menunjang liburan para wisatawan kuliner diatur melalui agen travel terkait dengan alasan kemudahan serta efisiensi waktu selama berlibur. Wisatawan yang berkunjung ke Kota Malang juga dapat dikategorikan dalam wisatawan usia produktif atau dalam angka yakni 21-30 tahun.

Daya serapan wisatawan yang berumur 30 tahun atau 40 tahun keatas masih sangat minim. Wisatawan yang berasal dari Kota-kota di sekitar wilayah Jawa Timur atau dengan kata lain wisatawan domestic juga masih mendominasi dalam angka yang cukup signifikan yakni 95\%, dan penyererapan wisatawan kuliner dari mancanegara masih sangat minim dengan jumlah angka besaran $5 \%$.

Dampak yang yang ditimbulkan dari adannya wisata kuliner masih menunjukan hasil-hasil yang positif dimana kemacetan yang masih dapat terurai, kebersihan kota yang masih sangat baik serta terbuka lebar nya lapangan pekerjaan bagi masyarakat lokal dan masyarakat dari kota lain di wilayah Jawa Timur yang ingin mencoba peruntungannya di Kota Malang dalam bidang wisata kuliner adalah bukti-bukti bahwa dampak wisata kuliner masih sangat positif dan dapat dikategorikan bisa berkelanjutan atau suistainable.

Saran dalam penelitian ini yaitu sinergisitas pemerintah dengan masyarakat lokal dalam penyelenggaraan wisata kuliner ini diharapkan terus dijaga dan dilakukan inovasi-inovasi baru dalam produktifitas kuliner di Kota Malang, dimana peran pemerintah sebagai fasilitator pegiat kuliner diharapkan terus menjadi sistem motorik dalam pergerakan wisata kuliner agar tidak menjadi fenomena yang hanya menjadi euphoria sesaat. Diharapkan para pegiat kuliner serta pebisnis dalam bidang pariwisata lain juga dapat terus menjaga segmen pasar wisatawan baru serta repeater guest.

\section{DAFTAR PUSTAKA}

Hall , Mitchell. 2011. Food Tourism Around the World: Development, Management and Markets. Jakarta: Indo Salemba Empat

Arikunto, Suharsimi. 2002. Metodologi Penelitian. Jakarta: Rineka Cipta.

Mill, Robert Christie. 2000. The Tourism International Business. Jakarta: Rajawali Pers.

Pitana, I Gede dan Gayatri. 2005. Sosiologi Pariwisata. Yogyakarta: ANDI.

Sugiyono. 2012. Memahami Penelitian Kualitatif. Bandung: Alfabeta.

. 2014. Metode Penelitian Manajemen. Bandung: Alfabeta.

Yoeti, Oka. 1996. Pengantar Ilmu Pariwisata Edisi Revisi. Bandung: Angkasa.

Bungin, Burhan. 2003. Analisis Data Penelitian Kualitatif . Jakarta: PT Raja Grafindo Persada 